\section{Prevention of War}

The Intelligent Man's Way to Prevent War. By Sir Norman Angell, Prof. Gilbert Murray, C. M. Lloyd, C. R. Buxton, Viscount Cecil, W. Arnold-Forster, Prof. Harold J. Laski. Edited by Leonard Woolf. Pp. 576. (London: Victor Gollancz, Ltd., 1933.) 5s. net.

"THE last word of evolution is this : The race is not to the swift nor to the strong but to the wise." With these words Dr. W. Langdon Brown closed an address on biology and politics in which he indicated certain general biological principles which bear on the political difficulties arising in the present conflict between nationalism and internationalism. Among the gravest needs of to-day is that of more intelligence in our national and international affairs, and anything which directs attention to this need is welcome. Nowhere is this more essential than in international affairs, both in our attitude to, and in thinking about, problems of world peace. Despite the quickening pulse of preparations for war during recent months, all the evidence goes to show that the general will to peace is much more conscious and decided than before the War, and there is no reason to question the sincerity of that desire. The growing danger of war is due mainly to lack of intelligent thinking about the problems involved, to a mental lethargy which refuses to face the full facts and to our tendency to desire two mutually inconsistent things.

The first step to world order is taken with the realisation that competition in national armaments, in place of giving security, leaves the relative position unchanged, and in fact tends to decrease security through the distrust and suspicion it breeds between the nations. The most serious feature of 1933 was the marked tendency in some quarters to forget the lesson impressed on men's minds in 1918-20 and to slip back into the pre-War mentality just when the Disarmament Conference was in session.

The second step towards world order is taken when it is generally realised that national defence rests fundamentally on pooled security and is a collective and not an individual matter. This view is, of course, implied alike in the Covenant of the League of Nations and in the Pact of Paris ; but even now not only are the full implications of such a system imperfectly understood by public opinion but also there is a gnawing anxiety as to whether the pledges given in such treaties will be observed.

These are not matters to which the scientific worker can be indifferent. Without urging that this is a matter which is peculiarly his responsi- bility, it is undoubtedly one in which he bears special responsibilities, and the lucid and impartial exposition of the various factors contained in "The Intelligent Man's Way to Prevent War" merits indeed the thoughtful attention of all scientific workers. Fundamentally, the problem is one of education, and the uncertainty whether the educational work can be completed in time to avoid disaster only emphasises the need for wholehearted support from the scientific worker.

As Dr. W. Langdon Brown pointed out in the address referred to above, while we are developing the need for larger and larger units in our social and industrial life, we are slow to restrict the impulses which tend to destroy such units. If we fail to adapt ourselves to the demands of evolution our civilisation will undoubtedly perish, and political events in 1933 do not encourage undue optimism. If, however, from an intellectual point of view there is reason for concern, biological considerations encourage optimism. The ease with which the body can throw off disease and return to health should safeguard us against the hasty belief that events in Japan or Germany, for example, inevitably presage a relapse into barbarism.

Moreover, the problem of security and disarmament, of world peace, is less technical than is commonly supposed. There are important technical factors, it is true, and there are problems to which the man of science can and should make an important specific contribution. What is even more important, however, is to destroy the feeling of mystery with which science is commonly surrounded, and by aiding ordinary intelligent people to appreciate the principles of science, to encourage the application of them to the everyday problems of a modern community. The enthronement of reason in place of prejudice thus secured would not mean the tyranny of experts, but would ensure that rational conduct of international affairs which would at once eliminate war. This point is well brought out by Sir Norman Angell in two chapters on "The International Anarchy" and on "Educational and Psychological Factors" which are among the most valuable in the book. They are to be commended to the scientific worker more than even Prof. Gilbert Murray's expert analysis of the possibilities and problems involved in revision of the peace treaties, Viscount Cecil's study of the League as a road to peace or $W$. Arnold-Forster's admirable discussion of the interlocked problems of arbitration, security and disarmament. Understanding of the issues there must be, but, above all, there must be action along the lines upon which the experts have already agreed that security and progress are possible.

R. BrightmaN. 